\title{
Correction to: Capacities of local maize seed enterprises in Mexico: implications for seed systems development
}

\author{
Jason Donovan ${ }^{1}\left[\right.$ Pieter Rutsaert ${ }^{2} \cdot$ Ciro Domínguez $^{3} \cdot$ Meliza Peña $^{1}$
}

Published online: 7 February 2022

(c) International Society for Plant Pathology and Springer Nature B.V. 2022

\section{Correction to: Food Security}

https://doi.org/10.1007/s12571-021-01247-8

The Acknowledgements section was missing from this article and should have read 'This study was carried out within the framework of the MasAgro Program, implemented by CIMMYT with funding provided by Secretariat of Agriculture and Rural Development (SADER), Mexico and the CGIAR research programs on Policies, Institutions and Markets (PIM) and Maize Agri Food System (MAIZE). Arturo Silva and Caritina Venado, with CIMMYT, provided valuable support with the logistics of primary data collection. We thank the representatives of numerous small-scale seed

companies who generously gave their time to participate in this study, as well as the anonymous reviewers and editors of this journal for their constructive comments on the manuscript. The contents and opinions expressed herein are those of the authors and do not necessarily reflect the views of the associated and supporting institutions'.

The original article has been corrected.

Publisher's Note Springer Nature remains neutral with regard to jurisdictional claims in published maps and institutional affiliations.

The original article can be found online at https://doi.org/10.1007/ s12571-021-01247-8.

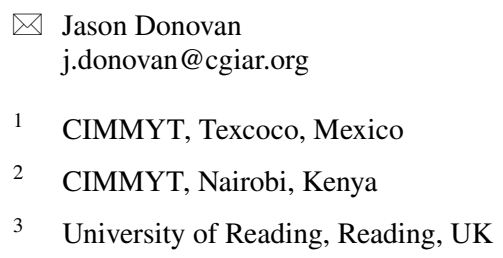

